\title{
The Influence of Pedagogical Competence on the Development of Psychomotor Aspects of Students of Physical Education Learning in SMAN 1 Sukabumi
}

\author{
Indra Ramadhan*, Tatang Muhtar, Haerul Ikhsan, Lufty Bela Dina Hakiki \\ Sport Education \\ Universitas Pendidikan Indonesia \\ Bandung, Indonesia \\ *indraramadhan@upi.edu
}

\begin{abstract}
This study discusses the influence of pedagogical competence to the development of aspects psychomotor students on physical education learning in SMAN 1 Sukabumi. This study focuses on aspect psychomotor students in learning physical education, by assessing those aspects of the physical education teacher pedagogical competence in SMAN 1 Sukabumi. The research method that used by the writer is descriptive quantitative method, with a population of class XI students of SMAN 1 Sukabumi and a sample of 30 people using random sampling. Based on the obtained results from this study is $r$ (correlation) between the two variables is 0.489 . The instrument that be used to collect the data was a questionnaire. It can be concluded that pedagogical competence to the development aspects of psychomotor students on physical education learning has a moderate relation. While the result of significant correlation coefficient both of variables is 2,996 with a value $t_{\text {tabel }}$ degree $n-2=28$, with a confidence level of 0.05 to be tested the two parties obtained $t_{\text {tabel }}$ of 2.408. Therefore, pedagogical competence towards the development aspects psychomotor students on physical education learning significantly. The conclusion of this study is: pedagogical competence has a positive relationship and significant impact on the development aspects of psychomotor students on physical education learning in SMAN 1 Sukabumi.
\end{abstract}

Keywords-pedagogic competence; psychomotor aspect; physical education learning

\section{INTRODUCTION}

Today education in Indonesia has undergone many changes and reforms. Change should be made because the education system must keep up with the times. For education in Indonesia to be even better. With these changes and updates, education in Indonesia is getting better.

Good quality of education, produces good students too. Good in understanding what is conveyed by educators, able to apply what is obtained in school into everyday life, able to socialize with fellow students and so on. All this can be realized if educators are competent in their fields to create good and quality students.
Teachers must have competencies related to how to educate students well. In the Minister of Education regulation, it is explained that teachers must have four competencies, including: pedagogic competence, personal competence, social competence and professional competence. A good educator must certainly have all four competencies. So that the teacher can educate the students well.

One of the competencies that must be possessed by a teacher is pedagogic competence. Pedagogic is the science that examines how to guide children, how educators deal with students, what is the task of educators in educating children, what is the goal of educating children [1]. Pedagogic is a study of teaching in formal education [2]. Pedagogic competence becomes very important because by mastering this competence the teacher can educate students well. Because in the pedagogic competence the teacher masters the methods in learning, the teacher masters student learning characteristics, the teacher can develop the curriculum, the teacher can create learning activities that educate and the teacher can assess the learning outcomes of students. Everything becomes very important because it influences student learning outcomes that involve three aspects of education, namely cognitive, affective, and psychomotor aspects.

Pedagogic is science that does not only examine its object to know something or the essence of the object and also living things [3]. Then interpreted also with education is an activity responsibly to realize the core of children's education, namely the act of educating morally against children.

Learning outcomes of students can be grouped into three domains, namely cognitive, affective, and psychomotor. These three domains cannot be explicitly separated from each other. Subjects that demand practical skills focus more on the psychomotor domain while subjects that demand theoretical ability focus more on the cognitive domain, and both always contain the affective domain. There are six skill levels, namely; reflex movements, Skills in basic movements, perceptual abilities, physical field abilities, such as strength, harmony and accuracy, skill movements, abilities related to non-decursive communication such as expressive and interpretative movements [4]. Psychomotor learning outcomes can be 
classified into six: "reflex motion, basic fundamental motion, perceptual ability, physical ability, skill movement, and wordless communication [5]. The classification of goals for psychomotor domains is divided into five categories, namely; imitation, manipulation, determination, articulation and automation [6].

Learning is the process of interacting students with educators and learning resources in a learning environment that includes teachers and students who exchange information. Learning can occur when there is cooperation or a relationship between two parties. In this case are educators (teachers) and students (students). Learning is influenced by six factors, namely goals, content or material, students, facilities, time, and teacher [7].

In short, learning can be interpreted as a product of ongoing interaction between development and life experience. Learning in complex meaning is a conscious effort from a teacher to teach his students (directing the interaction of students with other learning resources) by achieving the expected goals.

Physical education is a phase of the overall education process that is associated with strenuous activities that include the muscular system, as well as learning outcomes from participation in these activities [8]. Physical education is a phase of the overall education process that is associated with strenuous activities that include the muscular system, as well as learning outcomes from participation in these activities. Physical Education is an educational process that utilizes physical activity that is planned systematically which aims to improve individuals organically, neuromuscularly, perceptually, cognitively, and emotionally [9].

SMAN 1 is one of the favorite schools in the city of Sukabumi. In addition to creating good graduates, even this school has many athletes. However, in the process of learning physical education, many students do not follow the learning process well, so that the goals in learning physical education have not been well achieved. This also affects the psychomotor aspects that must be achieved by students. This problem occurs because of several factors. It could happen because of the students who do not follow the learning process properly, or the teacher who teaches but does not master pedagogic competence.

To reveal whether the teacher's pedagogic competence influences the development of psychomotor aspects of students in PJOK lessons, a study is needed. The purpose of this study was to determine the effect of pedagogic competence on the development of psychomotor aspects of students in PJOK learning in SMAN 1 Sukabumi City.

\section{METHOD}

\section{A. Population and Sample}

1) Population: To obtain data in this study required data sources called population and research samples. One of the favorite schools in the city of Sukabumi was chosen as a place of research. The population of this study were 10th grade students consisting of 15 classes. with a total of 519 students.
2) Sample: In this study the author uses the Simple Random Sampling technique. It is said to be simple because taking members of the sample from the population is done randomly without regard to the strata in the population [10]. The number of samples in this study were 30 students. The steps used in determining the sample are to record the number of 11 students in SMAN 1 Sukabumi City, then choose two students from each class to be examined in random sampling.

\section{B. Design and Procedure}

1) Design: This research uses descriptive method with a quantitative approach. Descriptive research aims to describe (describe) events that occur today. The description of the event was carried out systematically which emphasized data disclosure based on facts obtained from the field [11]. This research was conducted for two months. In this study, there are two variables, namely "Pedagogic Competence" as an independent variable, and "Student Psychomotor Aspect" as the dependent variable.

2) Procedure: After the permission is obtained from the school that will be used as a place of research, then determine the population and research sample. The instrument was prepared to obtain data from the sample, the instrument used in this study was a questionnaire. The question type in this questionnaire is a closed question. Closed questionnaires are questions that expect a short answer or expect the respondent to choose one of the answers to each of the questions that have been available. In preparing this instrument, the author uses a Variable model; sub variable; indicator; predictor; and item number ". This means that the sub-variables are broken down into indicators then each indicator is translated into a descriptor so that it can be easily formulated into the number of the questions or statements [12]. Two questionnaires were filled in by students, the first was a questionnaire to assess students 'psychomotor and the second was to assess teachers' pedagogical competencies. Validity and reliability tests are carried out before the instrument is used. After the data is obtained, the data is processed using statistical formulas. Then interpret the data from the results of data processing and make conclusions.

\section{Data Analysis}

To analyze the data, the first is to calculate the average and standard deviation of the data that has been obtained [13]. Then test the normality of the two variables. Comparison of the relationship between students' Pedagogic and Psychomotor Competencies by using the formula of product moment correlation coefficient. After that test the significance of the correlation between the two variables to determine the significance of the correlation between the two variables. If $t$ count $\leq \mathrm{t}$ table, then the correlation is not significant, if tcount $\geq$ ttable, the correlation is significant. Then look for a determination index that aims to find out how much the independent variable contributes to the dependent variable 


\section{RESULTS}

Data processing is done so that all data obtained contains meaning for research. The results of data processing in this research are as follows:

TABLE I. RESUlTS OF DATA PROCESSING

\begin{tabular}{|c|l|l|}
\hline Variable & \multicolumn{1}{|c|}{ Mean } & \multicolumn{1}{c|}{ SD } \\
\hline Pedagogic & 142,2 & 9,26 \\
\hline Psychomotor & 117,3 & 13.78 \\
\hline
\end{tabular}

In testing the normality of this data distribution, the authors apply normality testing and use the Lilliefors approach. The results of the normality test are as follows:

TABLE II. RESULTS OF THE NORMALITY TEST

\begin{tabular}{|c|l|l|l|}
\hline Variable & \multicolumn{1}{|c|}{ L-count } & L-table & Information \\
\hline Pedagogic & 0,10143 & 0,1610 & Normal \\
\hline Psychomotor & 0,1116 & 0,1610 & Normal \\
\hline
\end{tabular}

The table shows the L-count of the Pedagogic variable $=$ 0.10143 and Psychomotor $=0.1116$. From the results of the analysis, it can be concluded that the distribution of each variable turns out to be normally distributed.

To test whether there is a positive relationship between pedagogic competence and psychomotor aspects of students in Physical Education learning, the authors use the product moment correlation formula. With the results:

TABLE III. RESULT OF RELATIONSHIP BETWEEN PEDAGOGIC COMPETENCE AND PSYCHOMOTOR ASPECTS

\begin{tabular}{|c|c|c|c|c|}
\hline Variabel & $\begin{array}{c}\text { r- } \\
\text { count }\end{array}$ & $\begin{array}{c}\text { r- } \\
\text { table }\end{array}$ & $\begin{array}{c}\text { Interpretation } \\
\text { Table }\end{array}$ & Information \\
\hline Pedagogic & 0.489 & 0,374 & $0,40-0,599$ & Strong enough \\
\hline Psychomotor & 0.489 & 0,374 & $0,40-0,599$ & Strong enough \\
\hline
\end{tabular}

The results obtained are $r=0.489$. Therefore, it can be concluded that pedagogic competence in the development of psychomotor aspects of students in Physical Education learning has a moderate correlation, because $r=0.489$ is between 0.210 0.50 .

In testing the hypothesis used a test approach to the effectiveness of correlation $(r)$ pedagogic competence $(\mathrm{X})$ and psychomotor aspects of students in learning Physical Education (Y). The aim is to find out whether there is a significant relationship between pedagogic competence in the development of psychomotor aspects of students in Physical Education learning. By testing the hypothesis as follows:

TABLE IV. TESTING THE HYPOTHESIS

\begin{tabular}{|c|l|l|l|}
\hline Variable & \multicolumn{1}{|c|}{ t-count } & t-table & \multicolumn{1}{|c|}{ Information } \\
\hline Pedagogic & 2.996 & 2,048 & Significant \\
\hline Psycomotor & 2.996 & 2,048 & Significant \\
\hline
\end{tabular}

$\mathrm{H}_{0}$ : There is no significant influence between pedagogic competence and the development of students' psychomotor aspects.
$\mathrm{H}_{1}$ : There is a significant influence between pedagogic competence and the development of students' psychomotor aspects.

$$
\begin{aligned}
& \mathrm{H}_{0}: \mathrm{r}=0 \\
& \mathrm{H}_{1}: \mathrm{r} \neq 0
\end{aligned}
$$

\section{Testing criteria:}

If $t$ counts $\geq \mathrm{t}$ table, then reject $\mathrm{H}_{0}$ and is significant

If $t$ count $\leq \mathrm{t}$ table, then accept $\mathrm{H}_{0}$ and not significant

The results of the meaningfulness calculation were compared with the table values with degrees of freedom (df) n$2=30-2=28$ with a confidence level of 0.05 for the two-party test obtained t table of 2.048. Then tcount (2.996) $\geq$ table 2.048 then $\mathrm{HO}$ is rejected, meaning that there is a significant relationship between pedagogic competence on psychomotor aspects of students.

The results of the determination index determination in this study are obtained as follows:

$$
\begin{aligned}
\text { ID } & =r 2 \times 100 \% \\
& =0.4892 \times 100 \% \\
& =0.239 \times 100 \% \\
& =23.91 \%
\end{aligned}
$$

\section{DISCUSSION}

The purpose of this study is to find out how much influence the pedagogic competence has on the development of psychomotor aspects of students in Physical Education learning in SMAN 1 Sukabumi City. Data was obtained from 11th grade students by filling in the instrument, namely a questionnaire to assess the teacher's pedagogical competence and psychomotor aspects of the student.

As many as 30 people filled out questionnaires given by researchers. After data is obtained and data processing is done using the product moment formula to determine the correlation between two variables, namely pedagogic competence as independent variables and psychomotor aspects of students as dependent variables, it is known that there is a correlation between pedagogic competence on the development of students' psychomotor aspects.

The results of the data calculation show that a teacher's pedagogic competence has a major influence on the development of students' psychomotor aspects. If a teacher does not have pedagogic competence, the psychomotor aspects of students will not develop.

Hypothesis testing shows that $\mathrm{t}$-count $\geq \mathrm{t}$-table. This means that there is a significant relationship between teacher's Pedagogic Competency and Student Psychomotor aspects. The more teachers master pedagogical competence will also affect the psychomotor aspects of students.

To calculate how much the contribution of the teacher's pedagogical competence to the psychomotor aspects of students, then the calculation is used with the Determination Index formula. The result was $23.91 \%$. 
Then pedagogic competence gives as much as $23.91 \%$ influence for the development of psychomotor aspects of students. This means that the teacher's Pedagogic competence has a significant influence on the development of students' psychomotor aspects.

\section{CONCLUSION}

Based on the processing and analysis of data on pedagogic competence on the development of psychomotor aspects of students in Physical Education learning in SMAN 1 Sukabumi City, it can be concluded that the pedagogic competence of a teacher is very influential on the development of psychomotor aspects of students in learning Physical Education in SMAN 1 Sukabumi City.

\section{REFERENCES}

[1] U. Sadulloh, B. Robandi, and A. Muharam, Pedagogik. Bandung: Cipta Utama, 2007.

[2] M. Christine, Strategi dan Teknik Mengajar dengan Berkesan. Bandung: PT Setia Purna Inves, 2009.
[3] W. Rasyidin, Pedagogik Teoretis dan Praktis. Bandung: PT Remaja Rosdakarya Offset, 2014.

[4] N. Sudjana, Penilaian Hasil Proses Belajar Mengajar. Bandung: PT Remaja Rosda Karya Offset, 2009

[5] Purwanto, Evaluasi Hasil Belajar. Yogyakarta: Pustaka Pelajar, 2014.

[6] F. Maulana, Pengarah Kompetensi Pedagogik Terhadap Perkembangan Aspek Kognitif dan Psikomotor Siswa Pada Pembelajaran Penjas di SMK Wiraswasta Kota Cimahi. Skripsi Pada STKIP Pasundan Cimahi. Cimahi: tidak diterbitkan, 2013.

[7] D. Djadjuri, L. Saepuloh, and S.U. Rizal, Kurikulum dan Pembelajaran. Bekasi: CV Nurani, 2015.

[8] Sugiyono, Metode Penelitian Pendidikan. Bandung: Alfabeta, 2012.

[9] T. Subroto, Strategi Pembelajaran Pendidikan Jasmani. Jakarta: Universitas Terbuka, 2008.

[10] A.P. Mardiana and W.I. Satya, Pendidikan Jasmani dan Olahraga. Jakarta: Universitas Terbuka, 2008.

[11] M.E. Winarno, Metodologi Penelitian Dalam Pendidikan Jasmani. Malang: Media Cakrawala Utama Press, 2011.

[12] Riduwan, Skala Pengukuran Variabel-variabel Penelitian. Bandung: Alfabeta, 2007.

[13] Nurhasan, Dasar-dasar Statistika Sistem Pembelajaran Modul Mata Kuliah Statistika (inferensial) dan Penerapannya dalam Pendidikan. Cimahi: tidak diterbitkan, 2011. 